\title{
A Review on the Feasibility of Deployment of Renewable Energy Sources for Electric Vehicles under Smart Grid Environment
}

\author{
Femy P. H. ${ }^{1,2}$ and Jayakumar J. ${ }^{3}$ \\ ${ }^{I}$ Research Scholar, Department of Electrical and Electronics Engineering, Karunya Institute of Technology and Sciences, \\ Coimbatore, Tamil Nadu 641114, India; femyph@gmail.com \\ ${ }^{2}$ Assistant Professor, Department of Electrical and Electronics Engineering, KMEA Engineering College, Ernakulum, Kerala \\ 683561, India; femyph@gmail.com \\ ${ }^{3}$ Professor, Department of Electrical and Electronics Engineering, Karunya Institute of Technology and Sciences, Coimbatore, \\ Tamil Nadu 641114, India; jayakumar@karunya.edu
}

*Correspondence: Femy P. H.; Email: femyph@gmail.com

\begin{abstract}
Nowadays, Energy consumption in the field of transportation comes next to industrial consumption worldwide. If transportation is completely powered by renewable energy, the utilization of fossil fuels can be drastically reduced, which will result in a lesser amount of greenhouse gas emissions. Electric vehicles (EVs) can act as an alternative to make transportation pollution-free. Large-scale usage of EVs causes high electricity demand on the supply system. This problem can be overcome by utilizing renewable energy sources (RESs) for Electric Vehicle charging. Due to the unpredictability of RESs, coordinating EV charging with other loads and renewable generation is problematic. By using EVs as energy units, power fluctuations in the electric grid can be compensated. This paper presents a summary of recent research in the domain of integration of renewable energy sources with electric vehicles (EVs) under the smart grid environment. Electric vehicles-smart grid integrated systems face several issues related to communication, grid infrastructure and control in the future power system. Feasibility of integration of solar and wind energy systems with electric vehicles is discussed in section 2 . The existing research articles in this area are classified into two based on the purpose: EVs integration into the electric grid and Vehicle to grid services. The function of V2G in the electricity market, as well as its management concerns, are investigated in section 3. Finally, the research gaps and future scope of incorporating electric vehicles with renewable energy sources and the Smart grid are highlighted.
\end{abstract}

Keywords: Electric Vehicle, Renewable Energy Sources, V2G Services, Green Transportation, EV - Grid Integration, RES EV integration, Smart charging

\section{ARTICLE INFORMATION}

Author(s): Femy P. H., Jayakumar J.

Received: Dec 02, 2021; Accepted: Jan 20, 2022; Published: Jan 30, 2022; e-ISSN: 2347-470X;

Paper Id: IJEER-090306;

Citation: doi.org/10.37391/IJEER.090306

Webpage-link:

https://ijeer.forexjournal.co.in/archive/volume-9/ijeer-090306.html

\section{INTRODUCTION}

In order to assure a sustainable environment, dwindling fossil fuel reserves, global warming, and greenhouse gas (GHG) emissions must all be addressed. Transportation electrification is considered as a viable solution because the transportation industry is the second largest contributor to harmful emissions. EV technology has been around for about a century, with a commercial peak around the year 1900 .

The progress of electric vehicles is depicted in Figure 1. Transportation electrification lowered reliance on petroleum imports, thereby improving energy security. Due to issues like high initial investment, battery deterioration, limited charging facilities, range anxiety, and so on, the adoption rate of electric vehicles is still slow [1]. Governments throughout the world have launched a number of plans and incentives to stimulate the use of electric vehicles and accomplish a complete transition to electric transportation. According to the publication "Global EV Outlook" by the International Energy Agency, the electric vehicles may count up to 130 million by the end of 2030 [2].

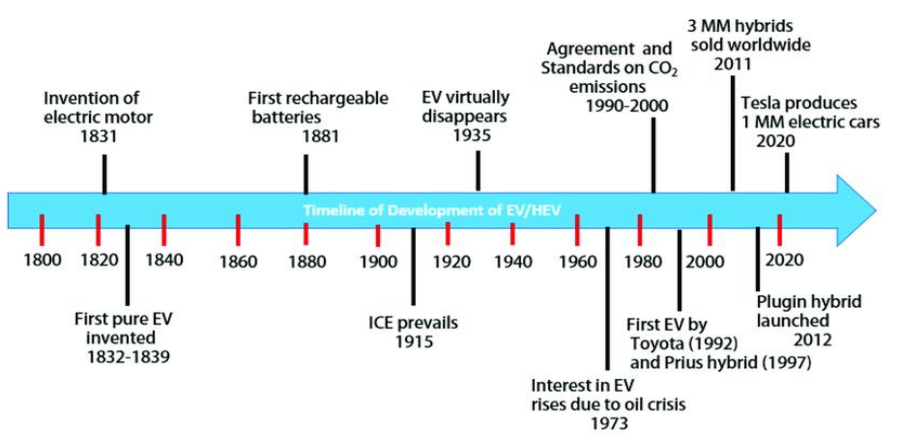

Figure 1. Development of electric vehicles (EVs)

Electric Vehicles are moving single-phase loads. As a result, they can be connected to distribution networks at any of the three phases. As a result, one phase's electrical components, such as a transformer, overhead line, or power supply cable, may be overloaded when compared to the remaining two phases, which are unloaded [3]. Because EVs are unpredictable in terms of timing, handling them as new loads 
while maintaining grid reliability and security is a challenge. EV home charging and residential load peaks occur at the same time, producing extra system peaks.

The conventional power industry based on fossil fuels is another significant source of harmful pollutants. Renewable sources (RES) like solar and wind are widely employed to reduce emissions in the power industry. Renewable energy's uncertainty, which is influenced by location, time, weather and other factors, causes voltage instability and grid reliability issues, necessitating the utilization of an energy storage system (ESS) [4]. Furthermore, the benefits of reduced emissions caused by electric transportation cannot be evaluated if nonrenewable sources are used for EV charging. EVs have been shown to produce more emissions in regions where fossil fuels are the primary source of energy [5]. Using RES to charge electric vehicles reduces GHG emissions [6]. Several publications in the literature have looked at the connection between the EV-PV system and the distribution network. The reference [7] examines charging electric vehicles with solar power, with an emphasis on control systems and algorithms, as well as the economic background. Reference [8] discusses the influence of EV charging circuits on power quality and the grid. References [9] provides an overview of EV modeling strategies, with a focus on EV load and charging station modeling.

Figure 2 shows a graphical plot of the number of publications reviewed on the subject of electric vehicles-renewable energy sources integration. About seventy research papers were chosen and examined from almost two hundred and twenty-six selected papers, based on their level of contribution to the area.

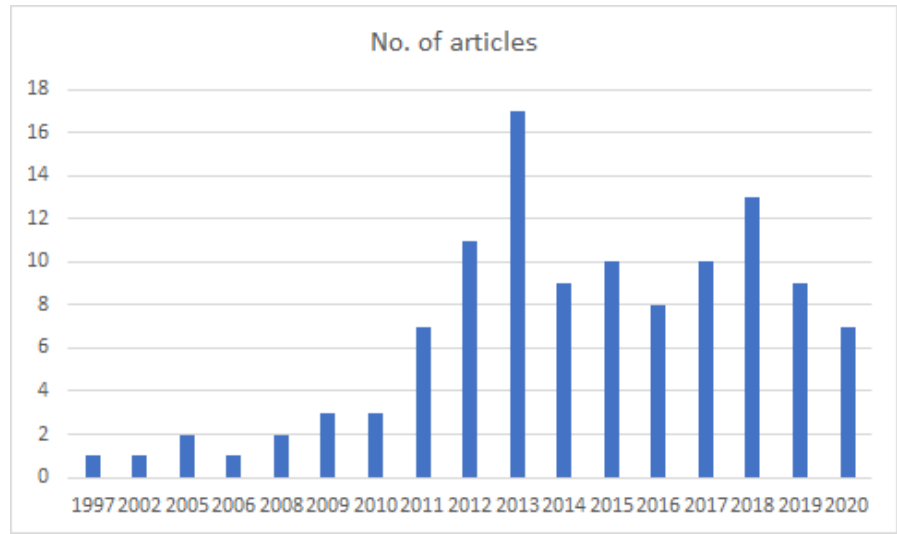

Figure 2. Articles plotted against years

The following is about the organization of the paper: The incorporation of EVC into the electric grid is explained in Section 2. The V2G services are reported in Section 3. Section 4 explains open issues and research directions, as well as concluding notes.

\section{ELECTRIC VEHICLE - GRID} INTEGRATION

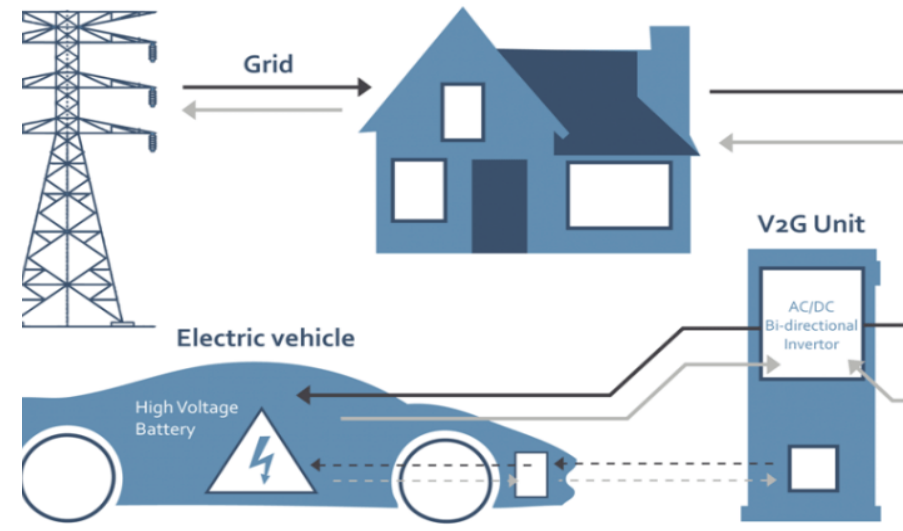

Figure 3. EV integration with the electric grid

Incorporating a large number of electric vehicles into the power grid is a massive problem that will require comprehensive investigation and monitoring in view of economic effects, control, and operation benefits under ideal circumstances. Many studies have examined the effect of electric vehicles on the power system [10], while others have examined specialized applications. Figure 3 displays a gridconnected electric vehicle $(\mathrm{EV})$. V2G is a technique that permits bidirectional energy flow between the grid and electric vehicles. A transition from unidirectional to bidirectional mode was seen in the modeling of EV connection with the distribution network.

The concomitant technical issues of EV penetration, such as greater system cost, system imbalance, poor stability, as well as power quality, are becoming increasingly visible as a result of rising energy and demand. The G2V mode (unidirectional approach) has been investigated in the literature in terms of smart charging [11], safety [12], and control features [13]. These studies aim to lower charging costs [14] or the effect on the distribution system [15].

In reversible mode, electric vehicles serve as a grid load as well as a distributed generating and storage system. Peak load shaving, or storing energy in electric vehicle batteries and sending it back to the utility at peak periods, is a concept that has been around for a while. Because each electric vehicle has a small battery, coordinating the charging and discharging procedures is a major challenge in making them act as a storage system. In order to perform the analysis of $\mathrm{G} 2 \mathrm{~V}$ and V2G modes, basic knowledge of EV battery energy consumption characteristics is required. Average energy consumption of EV battery pack is given by equation (1).

Average energy consumption of battery pack

$E a v g=(E p+E a u x)(2-\eta p) W h / K m$

Where Ep = Energy consumption for propulsion Eaux $=$ Energy consumption for auxiliary loads $\eta p=$ Efficiency of the powertrain 
The required battery pack total energy is given by

$$
E b p=E a v g * D v \text { Watt hours }
$$

Where $\mathrm{Dv}=$ Vehicle range in $\mathrm{km}$

The number of battery cells connected in series in a string is given by

$$
N c s=U b p / U b c
$$

Where Ubp $=$ Nominal battery pack voltage $(\mathrm{V})$ $\mathrm{Ubc}=$ Voltage of each battery cell $(\mathrm{V})$

The energy content of a string is obtained as

$$
E b s=N c s * \text { Ebc Watt hours }(W h)
$$

Where Ebc $=$ Energy of a battery cell $(\mathrm{Wh})$

The total number of strings of the battery pack is calculated by

$$
N s b=E b p / E b s
$$

The battery pack total energy Ebp can be recalculated as

$$
E b p=N s b * E b s \text { (Wh) }
$$

The battery pack capacity $\mathrm{Cbp}$ is calculated as

$$
\mathrm{Cbp}=\mathrm{Nsb} * \mathrm{Cbc} \text { (Ah) }
$$

Where Cbc is the capacity of the battery cell (Ah)

The total number of cells of the battery pack Ncb is given by

$$
N c b=N s b * N c s
$$

The battery pack peak current

$$
I b p p=I s p c * N s b_{(\mathrm{A})}
$$

Where Ispc $=$ string peak current $(\mathrm{A})$

The battery pack peak power

$$
P b p p=I b p p * U b p(\mathrm{~W})
$$

Previously, V2G simply entailed energy transmission from electric vehicles to the distribution infrastructure. $\mathrm{V} 2 \mathrm{H}$ and $\mathrm{V} 2 \mathrm{~V}$, on the other hand, are two novel energy transfer modes that have emerged as a result of technological advancements.

As a result, the transfer of energy from an EV can now be divided into three categories:

2(a) Vehicle-to-grid (V2G): Transfer of energy from EV to the

\begin{tabular}{|c|c|c|c|}
\hline & V2G & V2H & $\mathrm{V} 2 \mathrm{~V}$ \\
\hline \multirow[t]{6}{*}{ Features } & Large no. of EVs & $\begin{array}{l}\text { A single EV to } \\
\text { a single home }\end{array}$ & Multiple EVs \\
\hline & $\begin{array}{l}\text { Offering power } \\
\text { services through } \\
\text { the power grid }\end{array}$ & $\begin{array}{l}\text { Most simple, } \\
\text { Least flexible }\end{array}$ & $\begin{array}{l}\text { Power exchange } \\
\text { within the local grid }\end{array}$ \\
\hline & $\begin{array}{l}\text { Least simple, most } \\
\text { flexible }\end{array}$ & $\begin{array}{l}\text { Simple } \\
\text { infrastructure } \\
\text { requirements } \\
\text { and negligible } \\
\text { transmission } \\
\text { losses }\end{array}$ & $\begin{array}{l}\text { Less simple, Less } \\
\text { Flexible }\end{array}$ \\
\hline & Complex control & $\begin{array}{l}\text { Easy } \\
\text { installment }\end{array}$ & $\begin{array}{l}\text { Uncomplicated } \\
\text { infrastructure } \\
\text { requirements and } \\
\text { small transmission } \\
\text { losses }\end{array}$ \\
\hline & $\begin{array}{l}\text { High infrastructure } \\
\text { complexity and } \\
\text { significant } \\
\text { transmission losses }\end{array}$ & $\begin{array}{l}\text { Operation in } \\
\text { Home grid }\end{array}$ & $\begin{array}{l}\text { Operation in } \\
\text { community grid }\end{array}$ \\
\hline & $\begin{array}{l}\text { Operation in large } \\
\text { scale }\end{array}$ & & \\
\hline \multirow[t]{8}{*}{ Functions } & $\begin{array}{l}\text { Act as energy } \\
\text { sources to provide } \\
\text { grid ancillary } \\
\text { services }\end{array}$ & $\begin{array}{l}\text { Act as a home } \\
\text { backup } \\
\text { generator and a } \\
\text { controllable } \\
\text { load }\end{array}$ & $\begin{array}{l}\text { Act as energy } \\
\text { sources to other local } \\
\text { EVs }\end{array}$ \\
\hline & $\begin{array}{l}\text { Act as controllable } \\
\text { loads }\end{array}$ & $\begin{array}{l}\text { Cooperate with } \\
\text { domestic } \\
\text { electrical } \\
\text { devices for } \\
\text { load shift }\end{array}$ & $\begin{array}{l}\text { Reduce tariff by } \\
\text { trading power within } \\
\text { the local grid }\end{array}$ \\
\hline & $\begin{array}{l}\text { Release excess } \\
\text { energy back to the } \\
\text { grid at high priced } \\
\text { peak time }\end{array}$ & $\begin{array}{l}\text { Sell excess } \\
\text { energy back to } \\
\text { the grid at high } \\
\text { priced peak } \\
\text { time }\end{array}$ & $\begin{array}{l}\text { Increase the charging } \\
\text { and discharging } \\
\text { efficiency of EVs }\end{array}$ \\
\hline & $\begin{array}{l}\text { Act as distributed } \\
\text { storages }\end{array}$ & $\begin{array}{l}\text { Charge energy } \\
\text { at less } \\
\text { expensive off- } \\
\text { peak time }\end{array}$ & $\begin{array}{l}\text { Establish an isolated } \\
\text { V2V system }\end{array}$ \\
\hline & $\begin{array}{l}\text { Provide power for } \\
\text { the premise }\end{array}$ & $\begin{array}{l}\text { Contribute to } \\
\text { home grid or a } \\
\text { microgrid }\end{array}$ & $\begin{array}{l}\text { Coordinate control of } \\
\text { EVs }\end{array}$ \\
\hline & $\begin{array}{l}\text { Coordinate with } \\
\text { renewable energies }\end{array}$ & & $\begin{array}{l}\text { Reactive power } \\
\text { support }\end{array}$ \\
\hline & $\begin{array}{l}\text { Reactive power } \\
\text { support }\end{array}$ & & \\
\hline & $\begin{array}{l}\text { Stabilize the grid } \\
\text { for short periods }\end{array}$ & & \\
\hline
\end{tabular}
power grid.

2(b) Vehicle-to-home/building (V2H/V2B): Transfer of energy from EV to home/building.

2(c) Vehicle-to-vehicle (V2V): Transfer of energy from one EV to another EV.

Comparison of V2G, V2H and V2V schemes based on their features and functions is given in Table $I$.
Table 1: Comparison of V2G, V2H and V2V 


\subsection{Smart Charging of EVs Using RES and Grid}

The benefits of Electric Vehicle charging systems using photovoltaic panels have been examined in several research. Reference [16] states the benefits of charging electric vehicles using solar energy, demonstrating that it allows for greater PV and EV penetration. Excess PV generation can also be mitigated by electric vehicles [17]. According to reference [18], charging electric vehicles using solar panels is more costeffective and emits a lesser amount of $\mathrm{CO} 2$ than grid charging. In reference [19], the utilization of solar energy and the deployment of electric vehicles as energy storage units to reduce grid peak loads is considered. These studies show why Electric Vehicle charging using solar energy is preferable to grid-based EV charging [20]. All of the research in the field of smart charging concentrates on particular aspects of Electric Vehicle grid integration, such as slow/fast charging, market involvement, and auxiliary services [21]. References [22,23] are earlier studies on systems that combine a variety of topics that are often studied separately.

Smart charging, in combination with V2G technology, boosts PV self-consumption while lowering peak demand [24]. Unpredictability can be avoided by using sequential charging, which involves dynamically varying the number of Electric Vehicles undergoing constant power charging such that the PV generation is followed by net charging power [25]. In reference [26], numerous examples are investigated to prove that sequential charging outperforms concurrent charging in terms of solar power usage under stochastic conditions [27].

\subsection{Integration of Renewable energy sources with Electric Vehicles}

The introduction of renewable energy sources (RES) into the power system on a big scale is exciting. These sources, particularly PV solar energy and wind, provide an irregular and uncertain supply of electricity to the existing power infrastructure [28]. The majority of research found that the implementation of wind energy conversion systems (WECS) and photovoltaic solar systems into the power grid is quite realistic [29]. However, deploying stationary energy storage systems (ESS) or regulated dispatch loads [30] is a viable method for balancing the RES based power generation on the grid. When the power generation is excess, stationary energy storage devices absorb the electricity and supply it when the power generation is low [31]. EVs can consume excess energy produced by RES through various charging systems, or they can contribute energy to the grid during times of low energy production, thereby levelling grid operations [32]. According to [33], a feasible solution for maintaining energy security can be obtained by adding Renewable Energy Sources and adopting EVs that can supply V2G services. The integration of PV sources and wind into the electricity system with EVs is depicted in Figure 4. In the V2G mode, the electric vehicles are assembled at a charging station and used to decrease power variations from these RES [34].

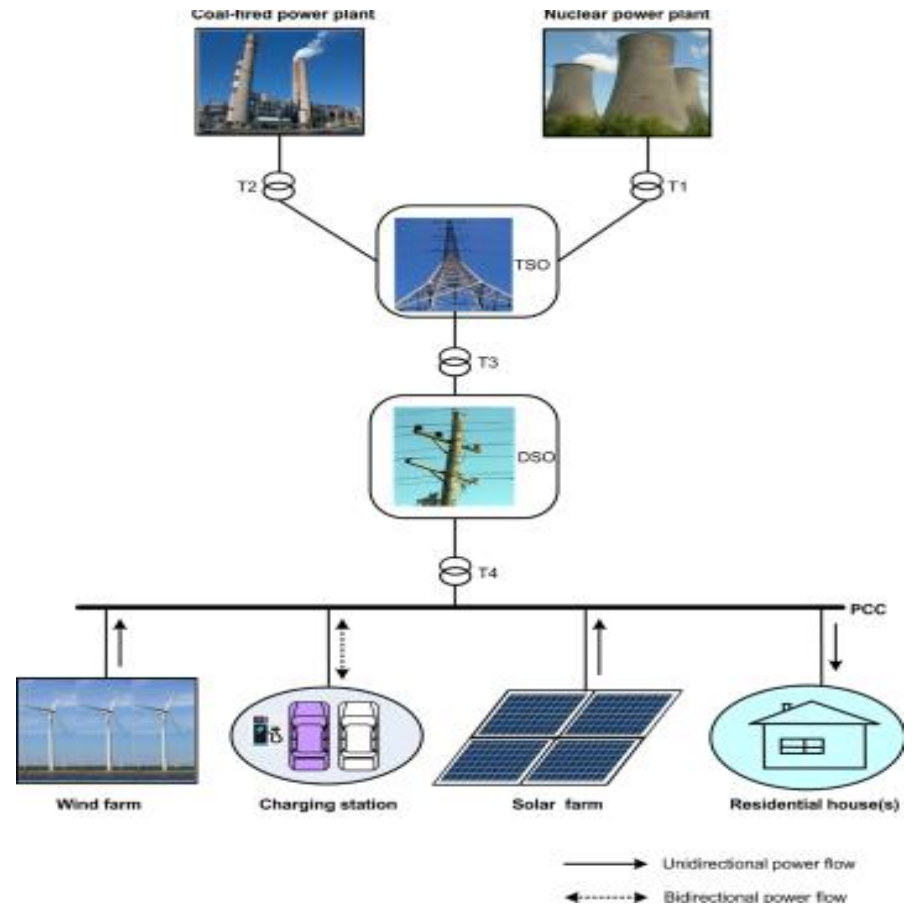

Figure 4. Integration of Electric Vehicles with Renewable Energy Sources and grid

\subsubsection{Feasibility of Solar Photovoltaic energy integration with $E V s$}

With the growing popularity of electric vehicles, solar PV power is expected to be used for grid support and EV charging. The deployment of solar panels on the roofs of parking areas for charging electric vehicles has been demonstrated to be quite exciting in numerous studies [35]. A solar car park charging station with a bidirectional DC to AC power converter linked to the electric grid is shown in Fig. 5. The diagram indicates how many charging points can be linked to the power system. Electric vehicles with a bidirectional DC charger, on the other hand, may absorb surplus power and are linked directly to the PV controller. According to [36], the DC electric grid is deemed to be a feasible and appealing solution in the power system architecture in future. It can also return stored power in batteries during peak load periods when solar power availability is low. [37] describes the research on the widespread use of PV panels on the rooftop and electric vehicles. Through V2G services, EVs can minimize the strain on the power distribution system. [38] provides a study of using solar panels on automobile parking areas in the Swiss city of Frauenfeld. According to the findings, PV installations on parking areas can meet $15 \%$ to $40 \%$ of EV energy requirements in the future [39]. 


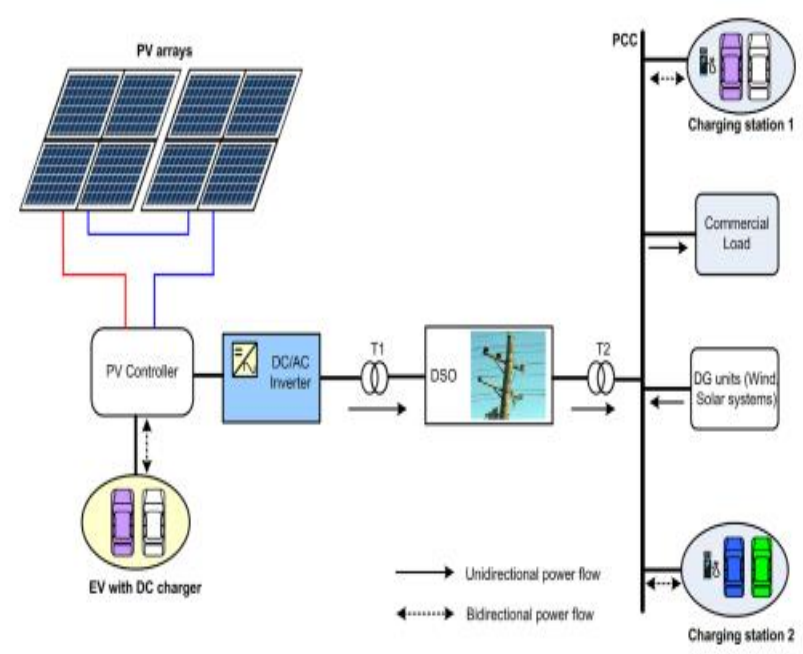

Figure 5. EV charging station with solar-powered grid-connected parking lot

\subsubsection{Feasibility of Wind energy integration with $\mathrm{EVS}$}

Wind farm-based energy conversion systems (WECSs) are an established and viable option for generating electricity. Various studies have explored the synergy between WECSs and EVs in various circumstances to determine their influence and viability on the electric grid [40]. Investigates the use of electric vehicles in the US energy market to provide subsidiary services and voltage management with WECSs. [41] did an interesting analysis on extensive inclusion of renewable energy sources (particularly wind) into the North-eastern Brazil power system utilizing plug-in hybrid electric vehicles between the years 2015 and 2030? [42] Analyzed the massive incorporation of wind energy conversion systems into the microgrid (MG) using PHEVs. Liu et al. [43] employed a twostage stochastic unit commitment model that takes into consideration interconnections between thermal power plants, plug-in hybrid electric vehicles, and large-scale wind farms [44].

\section{VEHICLE-TO-GRID (V2G) SERVICES}

Electric vehicles' batteries are primarily used for converting electrical energy into mechanical energy for propulsion. Feeding of energy back to the grid to increase grid reliability and stability is an additional feature of V2G [45]. According to [46], by 2030, around 56 million electric vehicles will be actively used on the road, with battery capacity averaging $120 \mathrm{kWh}$. Since vehicles spend most of their time in parking areas, the SG may make effective use of them when they are parked [47]. The function of V2G in the electricity market, as well as its management concerns, are investigated in order to better understand V2G's prospective applications in the SG [43].

\subsection{Voltage and Frequency Regulation Services}

Regulation services are concerned with automated generation control that adjusts the voltage and frequency of the system by balancing demand and supply. The regulation's stochastic nature and time sensitivity make it an ideal market for EVs
[48]. The capacity of V2G to compensate for reactive power was investigated in [49], with a focus on voltage regulation. Contracts with the SG are frequently required by AGs in order to settle down their service capacity and supply frequency regulation service [50]. Service capacity estimation is a new area of research due to restricted service capacity and EV mobility. Every quarter-hour, an AG model-based estimating approach is employed in [51] to keep track of EV frequency control capacity and forecast it. The major goal of a centrally managed scheduling is to maximize EV income [48], as the Regulation Up can generate concerns about battery depletion and range anxiety [52-57].

\subsection{Energy Management for V2G Services}

Based on the scheduling purpose, three different models of V2G operation exist. When house appliances are fed from EVs utilizing renewable energy sources, vehicle-to-home $(\mathrm{V} 2 \mathrm{H})$ mode is engaged. Vehicle-to-building (V2B) discharging is possible when electric vehicles (EVs) are parked at offices or recreation centers and are getting charged in the parking area. It is obvious that $\mathrm{V} 2 \mathrm{G}$ offers a wide variety of services, ranging from a single residential home to a large-scale microgrid.

\subsubsection{Demand Side Management (DSM)}

While electric vehicles discharge through aggregators, EV energy can be used to supply variable loads during peak hours, flattening the load profile. In DSM mode, the grid operator typically supervises the EV scheduling from a central location. As a result, V2G scheduling can be regarded as an optimization problem for lowering the scheduling cost.

\subsubsection{Load Flattening}

Load flattening is one of the primary V2G services in DSM. It is done by supplying excess demand with EV energy. Most of the electric vehicles will be in need of this service due to the long duration of peak load. However, the SoC state at the time of each EV's arrival and necessary departure SoC differ, necessitating adjustable scheduling and incentives to encourage them to discharge [58]. As a result, the cost of battery utilization is taken into account when determining the scheduling goal [59].

\subsubsection{Outage Management}

When the local grid is under maintenance, electric vehicles can act as energy suppliers. When there is a power outage at home, the primary goal of $\mathrm{V} 2 \mathrm{G}$ scheduling is to maintain the continuity of service [60-62]. The use of electric vehicles in outage management is required. The energy requirement can be fulfilled by using a large number of parked EVs [63], [64] or large-capacity EVs like electric buses [65]. Electric vehicle involvement has been discovered to reduce power interruption, ensure the regular functioning of an islanded microgrid, and decrease line loss.

\subsection{RES Integration}

A high number of RES-DGs can be included in the SG as a green energy supplement to mitigate the effects of increased greenhouse 
gas emissions. The output variability caused by environmentdependent power generation could jeopardize the system's reliability [64]. When connected to the SG and RES, EVs can store excess energy and fill up the energy gap when needed, acting as prospective energy storages that alleviate RES variability. In any residential building, renewable energy sources can be added into the smart grid as a second option, providing end-users with two benefits [66-69]. Firstly, employing renewable energy during peak hours minimizes the need for retail electricity, lowering overall electricity costs [70]. Second, RES assists in the provision of home appliances in the event of a power loss. Retarded demand response could result in wastage of energy for RES placed as a high-power rating farm. EVs can transport renewable energy to the energy required area in such instances [71].

\subsection{Roles and Challenges of V2G Services in the Electricity Market}

In terms of control mechanisms, the electrical market is divided into four submarkets: base power, spinning reserve, peak power, and regulation markets. However, EVs' movability and range anxiety difficulties may block a seamless role transition from loads to energy prosumers [72, 73]. When it comes to administering V2G services, the following considerations should be made:

1. The mobility of EVs adds to the V2G service's unpredictability and potential delay. While the damage can be mitigated in some circumstances through online generations.

2. For optimal V2G scheduling, electric vehicle depth-of-discharge (DoD) conditions and travel demands should be taken into account.

3. It's difficult to design data/command communication between the mobile EVs, SG, and AGs, because V2G services have a wide range of energy demands and reaction requirements [74].

\section{OPEN ISSUES AND RESEARCH DIRECTIONS}

Three key open concerns shared by various aspects of interaction of electric vehicles with renewable energy sources are addressed in this segment.

\subsection{Large scale RESs integration into the grid}

There is a substantial distinction between RES-producing facilities and traditional power plants [75]. When it comes to integrating RESs into the electricity grid, the differences between them and traditional generators provide significant challenges. Harmonic distortion, fault current, flicker, and voltage control are all issues that affect the local power system. Large-scale penetration of renewable energy sources into conventional power systems may necessitate a gradual overhaul of the power system and its operation methods.

\subsection{EVs battery utilization for RESs interaction}

If there is a surplus of electricity from RESs, it can be stored in an EV battery. The battery of an electric car can be discharged to provide electricity at the time of a power outage. The battery's charging-discharging cycle will be lengthened as a result of this. Almost every electric vehicle on the market today uses lithium-ion batteries. As the number of charging- discharging cycles rises, Li-ion batteries' power and capacity will decline dramatically. The battery's usable life will be shortened as a result.

\subsection{Feasibility of V2G supporting RESs interaction}

V2G technology is not supported by the majority of EVs currently on the market. The fundamental goal of EV adoption in the transportation industry is to phase out internal combustion engines. Some issues must be addressed in detail in order for V2G to be viable. To begin, EVs must have bidirectional power converters and modern communications devices to be able to use the V2G feature. Second, the charging station must include smart charging terminals which can connect with the electric vehicle's control unit. Finally, as the number of electric vehicles (EVs) grows, grid operators' control strategies will get more complex. In V2G, electric vehicles are primarily employed as a source of energy or as a form of energy storage. The distribution of EVs can't be predicted precisely because they're moving. This could cause issues with the power distribution network's ability to schedule energy between EVs, RES, and charging stations [76].

\section{CONCLUSION AND FUTURE WORK}

This research provided a thorough examination of how electric vehicles interact with smart grid infrastructure. The deployment of electric vehicles for the adoption of renewable sources to the smart grid has also been elaborated. Electric vehicles have been reported to supply subsidiary grid services such as frequency and voltage management, as well as reactive power support, in order to improve operational efficiency, lower power system running costs, and secure the electric grid. With sophisticated communication, control, and metering technologies, the study found that connecting EVs to the smart grid system would be conceivable. More studies are required, however, to support the V2G framework's acceptance over other energy storage methods. The final portion addresses open concerns and future research directions. This review is intended to help academicians and engineers gain a better knowledge of the field's current state and contribute more to it.

Conflicts of Interest: The authors declare no conflict of interest.

\section{REFERENCES}

[1] Asaad, M.; Shrivastava, P.; Alam, M.S.; Rafat, Y.; Pillai, R.K. Viability of $x E V s$ in India: A public opinion survey. In Lecture Notes in Electrical Engineering; Springer: Singapore, 2018; Volume 487, pp. 165-178.ISBN 9789811082481.

[2] Bunsen, T.; Cazzola, P.; Gorner, M.; Paoli, L.; Scheffer, S.; Schuitmaker, R.; Tattini, J.; Teter, J. Global EV Outlook 2018: Towards Cross-Modal Electrification; International Energy Agency: Paris, France, 2018.

[3] A. Mohammad, R. Zamora and T. T. Lie, "Integration of Electric Vehicles in the Distribution Network: A Review of PV Based Electric Vehicle Modelling," Energies 2020, 13, 4541. 
[4] Jordehi, A.R. Optimisation of demand response in electric power systems, a review. Renew. Sustain. Energy Rev. 2019, 103, 308319.

[5] Woo, J.; Choi, H.; Ahn, J. Well-to-wheel analysis of greenhouse gas emissions for electric vehicles based on electricity generation mix: A global perspective. Transp. Res. Part D Transp. Environ. 2017, 51, 340-350.

[6] Saber, A.Y.; Venayagamoorthy, G.K. Plug-in vehicles and renewable energy sources for cost and emission reductions. IEEE Trans. Ind. Electron. 2010, 58, 1229-1238.

[7] Fachrizal, R.; Shepero, M.; Van Der Meer, D.; Munkhammar, J.; Widén, J. Smart charging of electric vehicles considering photovoltaic power production and electricity consumption: A review. eTransportation 2020, 4, 100056.

[8] Yong, J.Y.; Ramachandaramurthy, V.K.; Tan, K.M.; Mithulananthan, N. A review on the state-of-the-art technologies of electric vehicle, its impacts and prospects. Renew. Sustain. Energy Rev. 2015, 49, 365-385.

[9] Ahmadian, A.; Mohammadi-Ivatloo, B.; Elkamel, A. A Review on plug-in electric vehicles: Introduction, Current status, and load modeling techniques. J. Mod. Power Syst. Clean Energy 2020, 8, 412-425.

[10] Green II RC, Wang L, Alam M. The impact of plug-in hybrid electric vehicles on distribution networks: a review and outlook. Renew Sustain Energy Rev 2011;15(1):544-53.

[11] Su, J.; Lie, T.; Zamora, R. Modelling of large-scale electric vehicles charging demand: A New Zealand case study. Electr. Power Syst. Res. 2019, 167, 171-182.

[12] Chung, C.-Y.; Youn, E.; Chynoweth, J.S.; Qiu, C.; Chu, C.-C.; Gadh, R. Safety design for smart Electric Vehicle charging with current and multiplexing control. In Proceedings of the 2013 IEEE International Conference on Smart Grid Communications (SmartGridComm), Vancouver, BC, Canada, 21-24 October 2013; pp. 540-545.

[13] Zheng, Y.; Niu, S.; Shang, Y.; Shao, Z.; Jian, L. Integrating plug-in electric vehicles into power grids: A comprehensive review on power interaction mode, scheduling methodology and mathematical foundation. Renew. Sustain. Energy Rev. 2019, 112, 424-439.

[14] He, Y.; Venkatesh, B.; Guan, L. Optimal scheduling for charging and discharging of electric vehicles. IEEE Trans. Smart Grid 2012, 3, 1095-1105.

[15] Hu, J.; You, S.; Lind, M.; Østergaard, J. Coordinated charging of electric vehicles for congestion prevention in the distribution grid. IEEE Trans. Smart Grid 2013, 5, 703-711.

[16] Denholm, P.; Kuss, M.; Margolis, R.M. Co-benefits of large scale plug-in hybrid electric vehicle and solar PV deployment. J. Power Sources 2013, 236, 350-356.

[17] Nunes, P.; Farias, T.L.; Brito, M.C. Day charging electric vehicles with excess solar electricity for a sustainable energy system. Energy 2015, 80, 263-274.

[18] Tulpule, P.; Marano, V.; Yurkovich, S.; Rizzoni, G. Economic and environmental impacts of a PV powered workplace parking garage charging station. Appl. Energy 2013, 108, 323-332.

[19] Kempton, W.; Tomi' c, J. Vehicle-to-grid power implementation: From stabilizing the grid to supporting large-scale renewable energy. J. Power Sources 2005, 144, 280-294.

[20] Teng Long, Qing-Shan Jia, Gongming Wang, Yu Yang, "Efficient Real-Time EV Charging Scheduling via Ordinal
Optimization", IEEE Transactions on Smart Grid, Vol. 12, No. 5, September 2021

[21] Qing-Shan Jia, Teng Long,"A review on charging behavior of electric vehicles: data, model, and control", Control Theory and Technology, 2020 - Springer

[22] Moghaddam, Z.; Ahmad, I.; Habibi, D.; Phung, Q.V.; Habibi, D. Smart charging strategy for electric vehicle charging stations. IEEE Trans. Transp. Electrif. 2018, 4, 76-88.

[23] Mouli, G.R.C.; Kefayati, M.; Baldick, R.; Bauer, P. Integrated PV charging of EV fleet based on energy prices, V2G, and offer of reserves. IEEE Trans. Smart Grid 2017, 10, 1313-1325.

[24] Van Der Kam, M.; Van Sark, W. Smart charging of electric vehicles with photovoltaic power and vehicle-to-grid technology in a microgrid; a case study. Appl. Energy 2015, 152, 20-30.

[25] Kadar, P.; Varga, A. PhotoVoltaic EV charge station. In Proceedings of the 2013 IEEE 11th International Symposium on Applied Machine Intelligence and Informatics (SAMI), Herl'any, Slovenia, 31 January-2 February 2013; pp. 57-60.

[26] Brenna, M.; Dolara, A.; Foiadelli, F.; Leva, S.; Longo, M. Urban scale photovoltaic charging stations for electric vehicles. IEEE Trans. Sustain. Energy 2014, 5, 1234-1241.

[27] Chien-Hsin Chung, Sidharth Jangra, Qingzhi Lai, and Xinfan Lin, "Optimization of Electric Vehicle Charging for Battery Maintenance and Degradation Management", IEEE Transactions on Transportation Electrification, Vol. 6, No. 3, September 2020

[28] International Electrotechnical Commission (IEC). Grid integration of large capacity renewable energy sources and use of large-capacity electrical energy storage. White paper 3; 2012.

[29] Dallinger D, Gerda S, Wietschel M. Integration of intermittent renewable power supply using grid-connected vehicles - a 2030 case study for California and Germany. Appl Energy 2013; 104:666-82.

[30] Battke B, Schmidt TS, Grosspietsch D, Hoffmann VH. A review and probalistic model of lifecycle costs of stationary batteries in multiple applications. Renew Sustain Energy Rev 2013; 25:240 50.

[31] F. Mwasilu, J. J. Justo, E. K. Kim, T. D. Do, J. W. Jung, "Electric vehicles and smart grid interaction: A review on vehicle to grid and renewable energy sources integration," Renewable and Sustainable Energy Reviews 34 (2014) 501-516.

[32] Richardson DB. Electric vehicles and electric grid: a review of modeling approaches, impacts and renewable energy integration. Renew Sustain Energy Rev 2013; 19:247-54.

[33] Saber AY, Venayagamoorthy GK. Plug-in vehicles and renewable energy sources for cost and emission reductions. IEEE Trans Ind Electron 2011; 58 (4):1229-39.

[34] Teng Long and Qing-Shan Jia, "Matching Uncertain Renewable Supply with Electric Vehicle Charging Demand-A Bi-Level Event-Based Optimization Method", Complex System Modeling and Simulation ISSN112096-9929 03/06 pp 33- 44 Volume 1, Number 1, March 2021 DOI:10.23919/ CSMS.2021.0001

[35] Tulpule P, Marano V, Yurkovich S, Rizzoni G. Economic and environmental impacts of a PV powered workplace parking garage charging station. Appl Energy 2013; 108:323-32.

[36] Birnnie III DP. Solar-to-vehicle (S2V) systems for powering commuters of the future. J Power Sources 2009; 186:539-42.

[37] Traube J, Lu F, Maksimovic D. Photovoltaic power System with integrated electric vehicle DC charger and enhanced grid 
support. In: Proceedings of the 15th International power electronics and motion control conference (EPE/PEMC); 2012.

[38] Derakhshandeh SY, et al. Coordination of generation scheduling with PEVs charging in industrial microgrids. IEEE Trans Power Syst 2013; 28(3):3451-61.

[39] Justo JJ, Mwasilu F, Lee J, Jung JW. AC-microgrids versus DCmicrogrids with distributed energy resources: a review. Renew Sustain Energy Rev 2013; 24: 387-405.

[40] Lopes JAP, Almeida PMR, Soares FJ. Using vehicle-to-grid to maximize the integration of intermittent renewable energy resources in islanded electric grids. In: Proceedings of the international conference on clean electrical power; 2009. p. 290 5 .

[41] Borba BSM, Szklo A, Schaeffer R. Plug-in hybrid electric vehicles as a way to maximize the integration of variable renewable energy in power systems: the case of wind generation in northeastern Brazil. Energy 2012; 37:469-81.

[42] Wu T, Yang Q, Bao Z, Yan W. Coordinated energy dispatching in microgrid with wind power generation and plug-in electric vehicles. IEEE Trans Smart Grid 2013;4(3):1453-63.

[43] Liu C, Wang J, Botterud A, Zhou Y, Vyas A. Assessment of impacts of PHEV charging patterns on wind-thermal scheduling by stochastic unit commitment. IEEE Trans Smart Grid 2012;3(2):675-83

[44] Wei Wang, Liu Liu, Jizhen Liu, and Zhe Chen, "Energy Management and Optimization of Vehicle-to-grid Systems for Wind Power Integration", CSEE Journal of Power and Energy Systems, Vol. 7, No. 1, January 2021

[45] W. Su, H. Rahimi-Eichi, W. Zeng, and M.-Y. Chow, "A survey on the electrification of transportation in a smart grid environment," IEEE Trans. Ind. Informat., vol. 8, no. 1, pp. 110, Feb. 2012.

[46] P. Cazzola, M. Gorner, L. Munuera, R. Schuitmaker, and E. Maroney, "Global EV outlook 2017," Int. Energy Agency, Paris, France, Rep., 2016.

[47] S. Letendre, P. Denholm, and P. Lilienthal. (2006). Electric and Hybrid Cars: New Load or New Resource? [Online]. Available: http://www.fortnightly.com/pur_search_r.cfm

[48] J. J. Escudero-Garzás, A. García-Armada, and G. SecoGranados, "Fair design of plug-in electric vehicles aggregator for V2G regulation," IEEE Trans. Veh. Technol., vol. 61, no. 8, pp. 3406-3419, Aug. 2012.

[49] G. Buja, M. Bertoluzzo, and C. Fontana, "Reactive power compensation capabilities of V2G-enabled electric vehicles," IEEE Trans. Power Electron., vol. 32, no. 12, pp. 9447-9459, Dec. 2017.

[50] A. Lam, K.-C. Leung, and V. O. K. Li, "Capacity estimation for vehicle-to-grid frequency regulation services with smart charging mechanism," IEEE Trans. Smart Grid, vol. 7, no. 1, pp. 156-166, Jan. 2016.

[51] H. Zhang, Z. Hu, Z. Xu, and Y. Song, "Evaluation of achievable vehicle-to-grid capacity using aggregate PEV model," IEEE Trans. Power Syst., vol. 32, no. 1, pp. 784-794, Jan. 2017.

[52] R. Wang, Y. Li, P. Wang, and D. Niyato, "Design of a V2G aggregator to optimize PHEV charging and frequency regulation control," in Proc. IEEE Int. Conf. Smart Grid Commun., Vancouver, BC, Canada, 2013, pp. 127-132.

[53] K. Janfeshan and M. A. S. Masoum, "Hierarchical supervisory control system for PEVs participating in frequency regulation of smart grids," IEEE Power Energy Technol. Syst, vol. 4, no. 4, pp. 84-93, Dec. 2017.

[54] E. L. Karfopoulos, K. A. Panourgias, and N. D. Hatziargyriou, "Distributed coordination of electric vehicles providing V2G regulation services," IEEE Trans. Power Syst., vol. 31, no. 4, pp. 2834-2846, Jul. 2016.

[55] J. Tan and L. Wang, "A game-theoretic framework for vehicleto-grid frequency regulation considering smart charging mechanism," IEEE Trans. Smart Grid, vol. 8, no. 5, pp. 23582369, Sep. 2017.

[56] M. Yilmaz and P. T. Krein, "Review of charging power levels and infrastructure for plug-in electric and hybrid vehicles," in Proc. IEEE Int. Elect. Veh. Conf., Greenville, SC, USA, 2012, pp. 1-8.

[57] U. K. Madawala and D. J. Thrimawithana, "A bidirectional inductive power interface for electric vehicles in V2G systems," IEEE Trans. Ind. Electron., vol. 58, no. 10, pp. 4789-4896, Oct. 2011.

[58] V. N. Coelho et al., "Multi - objective energy storage power dispatching using plug-in vehicles in a smart-microgrid," Renew. Energy, vol. 89, pp. 730-742, Apr. 2016.

[59] N. Chen, M. Li, M. Wang, J. Ma, and X. Shen, "Compensation of charging station overload via on-road mobile energy storage scheduling," in Proc. IEEE Global Commun. Conf. (GLOBECOM), Washington, DC, USA, Dec. 2019, pp. 1-6.

[60] Maigha and M. L. Crow, "Electric vehicle scheduling considering co-optimized customer and system objectives," IEEE Trans. Sustain. Energy, vol. 9, no. 1, pp. 410-419, Jan. 2018.

[61] A. Alahyari, M. Fotuhi-Firuzabad, and M. Rastegar, "Incorporating customer reliability cost in PEV charge scheduling schemes considering vehicle-to-home capability," IEEE Trans. Veh. Technol., vol. 64, no. 7, pp. 2783-2791, Jul. 2015.

[62] N. Z. Xu and C. Y. Chung, "Reliability evaluation of distribution systems including vehicle-to-home and vehicle-togrid," IEEE Trans. Power Syst., vol. 31, no. 1, pp. 759-768, Jan. 2016.

[63] I. G. Unda, P. Papadopoulos, S. Skarvelis-Kazakos, L. M. Cipcigan, N. Jenkins, and E. Zabala, "Management of electric vehicle battery charging in distribution networks with multiagent systems," Elect. Power Syst. Res., vol. 110, pp. 172-179, May 2014.

[64] Farzin, M. Fotuhi-Firuzabad, and M. Moeini-Aghtaie, "Reliability studies of modern distribution systems integrated with renewable generation and parking lots," IEEE Trans. Sustain. Energy, vol. 8, no. 1, pp. 431-440, Jan. 2017.

[65] H. Gao, Y. Chen, S. Mei, S. Huang, and Y. Xu, "Resilienceoriented pre-hurricane resource allocation in distribution systems considering electric buses," Proc. IEEE, vol. 105, no. 7, pp. 1214-1233, Jul. 2017.

[66] S. Shafiq and A. T. Al-Awami, "Reliability and economic assessment of renewable micro-grid with $\mathrm{V} 2 \mathrm{G}$ electric vehicles coordination," in Proc. IEEE Jordan Conf. Appl. Elect. Eng. Comput. Technol., 2015, pp. 1-6.

[67] A. Kavousi-Fard, T. Niknam, and M. Fotuhi-Firuzabad, "Stochastic reconfiguration and optimal coordination of V2G plug-in electric vehicles considering correlated wind power generation," IEEE Trans. Sustain. Energy, vol. 6, no. 3, pp. 822830, Jul. 2015. 
[68] L. Liu, F. Kong, X. Liu, Y. Peng, and Q. Wang, "A review on electric vehicles interacting with renewable energy in smart grid," Renew. Sustain. Energy Rev., vol. 51, pp. 648-661, Nov. 2015.

[69] S. Wang, Z. Y. Dong, F. Luo, G. Ranzi, and Y. Qiao, "Stochastic residential energy management system with vehicleto-home and photovoltaic penetration," in Proc. IEEE Power Energy Soc. Gen. Meeting (PESGM), Aug. 2018, pp. 1-5.

[70] X. Wu, X. Hu, X. Yin, and S. J. Moura, "Stochastic optimal energy management of smart home with PEV energy storage," IEEE Trans. Smart Grid, vol. 9, no. 3, pp. 2065-2075, May 2018.

[71] P. Yi et al., "Renewable energy transmission through multiple routes in a mobile electrical grid," in Proc. IEEE Power Energy Soc. Innov. Smart Grid Technol. Conf., Washington, DC, USA, 2014, pp. 1-5.

[72] K. Rajashekara, "Present status and future trends in electric vehicle propulsion technologies," IEEE J. Emerg. Sel. Topics Power Electron. vol. 1, no. 1, pp. 3-10, Mar. 2013.

[73] N. Chen, M. Wang, N. Zhang, and X. Shen, "Energy and Information Management of Electric Vehicular Network: A

Survey," IEEE Comm. Surveys \& Tutorials, vol. 22, no. 2, pp. 967-997, Second Quarter 2020

[74] N. Chen, J. Ma, M. Li, M. Wang, and X. Shen, "Energy management framework for mobile vehicular electric storage," IEEE Netw., vol. 33, no. 6, pp. 148-155, Nov. 2019.

[75] Liansheng Liu, Fanxin Kong, Xue Liu, Yu Peng, Qinglong Wang, "A review on electric vehicles interacting with renewable energy in smart grid," Renewable and Sustainable Energy Reviews 51 (2015) 648-661.

[76] Shubhani Aggarwal, Neeraj Kumar, "PETS: P2P Energy Trading Scheduling Scheme for Electric Vehicles in Smart Grid Systems", IEEE Transactions on Intelligent Transportation Systems November 2021.

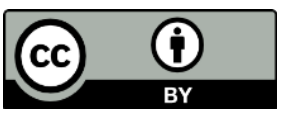

BY) license
(C) 2021 by the Femy P. H., Jayakumar J. Submitted for possible open access publication under the terms and conditions of the Creative Commons Attribution (CC (http://creativecommons.org/licenses/by/4.0/). 